\title{
Status and Distribution Pattern of Barking Deer (Muntiacus muntjak Zimmermann) in Hemja VDC, Kaski
}

\author{
K. Pokharel and M. K. Chalise \\ Central Department of Zoology, Tribhuvan University Kirtipur, Kathmandu \\ e-mail:mukesh57@hotmail.com
}

\begin{abstract}
Barking deer (Muntiacus muntjak Zimmermann) is a solitary and forest dwelling ruminant. A study was carried out to know status and distribution of barking deers found in the forested mountains of Hemja VDC, Kaski District. The study was done by direct observation method with indirect counting of fecal pellets while walking systematically in total 11 line transects covering $6.64 \mathrm{~km}$ in length and a total of 20 quadrates with $20 \times 20 \mathrm{~m}^{2}-40 \times 40 \mathrm{~m}^{2}$ randomly laid down in three different sites of the study area. A total of 12 individuals ( 5 adult males, 4 adult females, 2 sub-adult females and 1 infant), 178 pellet groups, 13 latrines and one hunting spot were recorded inside three different blocks of the study area. The results showed clumped and uneven distribution of this deer. It prefers middle range of the mountain (1100-1300m) with dense canopy cover, proper water sources and less human disturbances.
\end{abstract}

Key words: barking deer, distribution pattern

\section{Introduction}

The muntjac or barking deer (Muntiacus muntjak Zimmermann) is a small forest dwelling ruminant (Teng et al. 2004). Muntjac deer are classified into 9 known species: Muntiacus crinifrons, M. feae, $M$. gongshanensis, M. muntjak, M. putaoensis, M. reevesi, $M$. rooseveltorum, $M$. truongsonensis and $M$. vuquangensis (Shi and Ma 1988, Amato et al. 1991, Nowak 1991, Giao et al. 1998, Wang \& Lan 2000). There are 15 subspecies of the Muntjak in the world (Ohataishi \& Gao, 1990). The species found in Nepal, Bhutan and Northern India is M. muntjak vaginalis (Tamang 1982). Barking deer is primarily a solitary species (Kurt 1981, Heggdal 1999) and can be seen occasionally in a group of 4 or 5 animals (Kurup 1971). They are shy and secretive creature (Kurt 1981). Muntjacs exhibit two patterns of defecation in captivity and even in wild. They defecate through their enclosure without regard to existing pellet groups, and they repeatedly use specific areas, which are called latrines (Dubost 1970). The barking deer are not listed in the IUCN Red List of Threatened Species. The barking deer is common species in Nepal and is called
'Rate' or 'Ratuwa' locally. It is supposed to be the smallest deer in shape among its family and color variation is observed in different ecological zones of Nepal. It is seen scarcely distributed in small number due to habitat loss and hunting in the country except in protected areas (Chalise 2001).

\section{Methodology}

\section{Study site}

Hemja VDC, a probable buffer zone of Annapurna Conservation Area (ACA) is never studied for wildlife. So, information on flora and fauna found in Hemja VDC is still lacking. This VDC (83052'43"-83058'30" E and $28^{0} 14^{\prime} 52^{\prime \prime}-28^{0} 18^{\prime} 00^{\prime \prime} \mathrm{N}$ ) is northern-most boarder of Pokhara valley covering $13.31 \mathrm{~km} 2$ area. It is about $10 \mathrm{~km}$ far from Pokhara, the headquarters of Kaski district. The study area lies in the southern boarder of ACA, so it is a probable buffer zone of ACA. The main mountainous range of the area runs in southeast to northwest direction with its highest peak at Paripakha (1786m), which rises abruptly from the floor of Pokhara valley $(900 \mathrm{~m})$. The study area is boarded by Seti river on the east and by Kaskikot VDC in the west. Pokhara- 
Baglung highway crosses $11.5 \mathrm{~km}$ through the Hemja VDC from south to northwest (Fig-1). It is connected with Lahachok and Dhital VDCs at the northern border and Naudada/Nagdada and Dhikur Pokhari at the western border. Similarly, the border of Kaskikot and Pokhara at the south surrounds it. In addition to the muntjac, other mammals in Hemja VDC include wild cat (Felis chaus), leopard (Panthera pardus), mangoose (Herpestes spp.), Langur monkey (Semnopithecus entellus), Rhesus monkey (Macaca mulatta), etc. (Pokharel 2006).

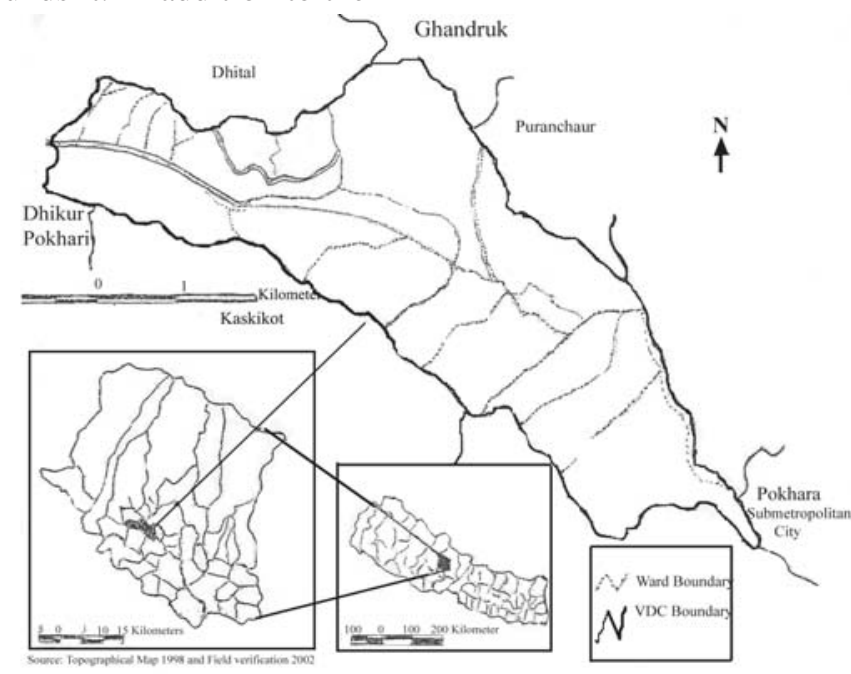

Fig.1. Location of the study area in Kaski, Nepal

\section{Study design}

The reconnaissance survey in the area for the research was carried out during the month of July of 2005. Realizing the information by initial survey, study was focused on three different sites of the area. The field survey was carried out to collect data on individuals and fecal pellets of barking deer from October 2005 to July 2006. There are two mountain ridges in the study area that include both faces of northern mountain ridge (Jhijhirka Ban, 1530m) and northern face of southern mountain ridge (Paripakha Ban, 1786m). Each face of the mountains was considered as a single block. Northern face of Jhijhirka Ban was considered as Block A, while that of southern face and its associated landmass was considered as Block B. Similarly, northern face of Paripakha Ban and its associated landmass taken as Block C. Regular monitoring of barking deer was done through transects of $0.4-1.6 \mathrm{~km}$ in length for a total of $6.64 \mathrm{~km}$, laid out in different blocks of the area. Those transects covered all the habitat types of the study area crossing north to south by some transects and east to west for others. Block A, B and C contained 3, 3 and 5 transects respectively according to feasibility of topography. The animals sighted within 50m in each side of transect and evidence of its presence such as pellets sighted within $5 \mathrm{~m}$ in each side of transect were recorded. At each evidence sign, location and altitude were recorded. On these transects, a total of 20 quadrates with $20 \times 20 m^{2}-40 \times 40 m^{2}$ were laid down to record the fecal deposits of animals. Block A, B and C contained 6, 6 and 8 quadrates respectively. The field observation was carried out from 5.15am to 6.50pm. Comparatively similar amount of time was spent in each block for data collection. Age group of barking deer was distinguished by their body proportion, height and size. Since horns are found only in male, age estimation of male was on the basis of size of horn (Fig. 3).

Considering characteristics of animal size and behaviors the following categories of age groups were decided.

Infants: Very small body size, found hiding in bush and remained associated with mother.

Juvenile: Small body size, not more than 1- year old, moving in group or might be solitary. 
Sub-adult: Individuals with 1-2 years of age and estimated height at shoulder was not more than $45 \mathrm{~cm}$. Similarly, individuals with noticeable horns were considered as sub-adult males and without horns at the same height were considered as sub-adult female.

Adult: Adults of both sexes were estimated to be over 2 years of age and more than $45 \mathrm{~cm}$ in height. Males had developed bifurcated horns with approximately $10 \mathrm{~cm}$ or more in length.

Droppings and piles were categorized into random droppings and relic sites as defined below.

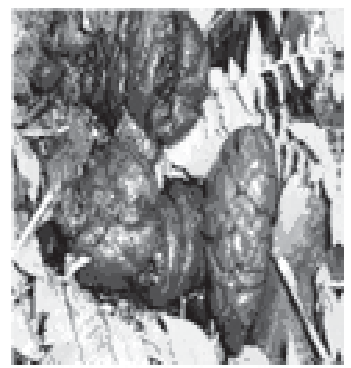

Fig 2. Very fresh fecal pellets of barking deer

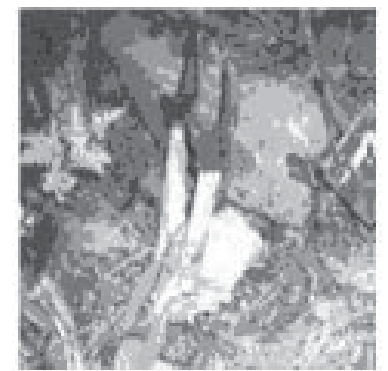

Fig. 3. Horn remains of barking deer

\section{Results}

A total of 12 individuals of barking deer (5 adult males, 4 adult females, 2 sub-adult females and one infant), 178 pellet groups and 13 relic sites were recorded during study period. A total of $2.76 \mathrm{~km}^{2}$ area $(21.02 \%$ of the total area) was sampled. Highest density of fecal pellets was observed in block A while lowest in block B (Table-1). However, chi-square goodness of fit test revealed that there were no significant differences in distribution of pellet groups in three different blocks $\left[\left(\chi^{2}(=5.15)<\chi_{0.05}^{2}\right.\right.$ at 2 d.f. $]$

Table 1. Distribution of barking deer pellet groups in different blocks

\begin{tabular}{l|l|c}
\hline Block & Pellet group & Density $\mathbf{( k m}^{-2} \mathbf{)}$ \\
\hline A & 44 & 78.57 \\
B & 56 & 52.58 \\
C & 78 & 68.12 \\
\hline
\end{tabular}

Latrines recorded in the area are tabulated with an interval of $100 \mathrm{~m}$ in altitude (Table 2 ). No any latrines were recorded above $1500 \mathrm{~m}$ of altitude. This area was least used by deer and it might be due to the steepness
Random droppings: A deposit of feces excreted single time anywhere in the study area.

Latrines (Relic site): It is the latrine of barking deer. It contains huge deposits of feces of different period (Fig. 2 -5 for muntjack evidences of droppings and others characters.

All the collected information were tabulated according to the objective of the study. Data were manually processed and analyzed in descriptive way as well by statistical measures.

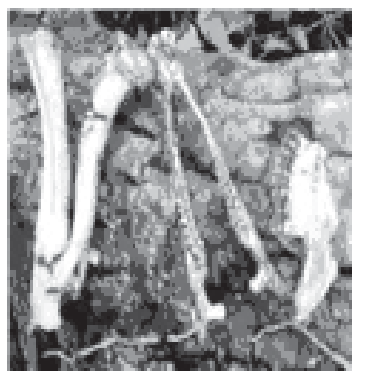

Fig. 4. Bone remains of barking deer

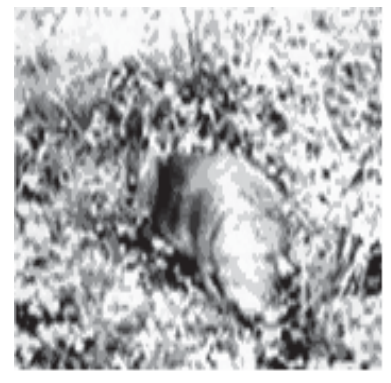

Fig. 5. Barking deer in resting state of mountain $(\sim 800)$. Altitudinal range having with maximum number of dung piles recorded was $1200 \mathrm{~m}-$ $1300 \mathrm{~m}$ which was found to be $38.46 \%$ of total observed dung piles (13 sightings). Most of the deer were sighted in the altitudinal range of $1100 \mathrm{~m}-1300 \mathrm{~m}$ which covers the $75 \%$ of total deer sighted records. A scattered distribution was recorded to 1301 to 1500 meter above the sea level of mountain slope. No deer was sighted in the lower range of the mountain below $1100 \mathrm{~m}$ and above $1500 \mathrm{~m}$ elevation during the study period (Table 2).

Table 2. Distribution of barking deer and latrines in relation to altitude

\begin{tabular}{l|c|l|l|l}
\hline $\begin{array}{l}\text { Altitudinal } \\
\text { range }\end{array}$ & $\begin{array}{l}\text { Dung } \\
\text { Piles No. }\end{array}$ & $\begin{array}{l}\text { Percentage } \\
\text { (\%) }\end{array}$ & $\begin{array}{l}\text { Deer } \\
\text { sighted }\end{array}$ & $\begin{array}{l}\text { Percen } \\
\text { tage (\%) }\end{array}$ \\
\hline $1000 \mathrm{~m}-1100 \mathrm{~m}$ & 2 & 15.38 & 0 & 0 \\
$1101 \mathrm{~m}-1200 \mathrm{~m}$ & 4 & 30.77 & 4 & 33.33 \\
$1201 \mathrm{~m}-1300 \mathrm{~m}$ & 5 & 38.46 & 5 & 41.67 \\
$1301 \mathrm{~m}-1400 \mathrm{~m}$ & 1 & 7.70 & 1 & 8.33 \\
$1401 \mathrm{~m}-1500 \mathrm{~m}$ & 1 & 7.70 & 2 & 16.67 \\
$>1500 \mathrm{~m}$ & 0 & 0.00 & 0 & 0 \\
\hline
\end{tabular}


Chi-square of goodness-of-fit test $\left[\chi^{2}(=66.91)>\chi^{2}{ }_{0.05}\right.$ at 5 d.f.] showed that there has significant difference in distribution of dung piles in relation to altitudinal range.

Barking deer were observed only for a few seconds. They escaped in lightening speed when they noticed any kind of disturbance. Most of the deer were sighted in gorges. Barking deer with different age groups were recorded in different altitude mainly in the morning around 6 to 10 am (Table 3). Adult and sub-adult muntjaks were seen solitary while dependent infants were associated with mothers.

Table 3. Observation of barking deer in different altitude of the area and sighted time (Nepali standard time).

\begin{tabular}{l|l|c}
\hline Age group/sex & Altitude (m) & $\begin{array}{r}\text { Sighted } \\
\text { Time(am) }\end{array}$ \\
\hline Adult male & 1120 & 7.10 \\
Adult male & 1190 & 7.30 \\
Adult male & 1320 & 7.15 \\
Adult male & 1445 & 8.10 \\
Adult male & 1155 & 7.30 \\
Adult female & 1210 & 6.35 \\
Adult female & 1255 & 9.15 \\
Adult female & 1175 & 8.05 \\
Adult female & 1440 & 8.10 \\
Sub adult female & 1250 & 6.20 \\
Sub adult female & 1230 & 7.10 \\
Infant & 1255 & 9.15 \\
\hline
\end{tabular}

\section{Discussion}

In Hemja VDC, the barking deer distribution at different habitats was found to be clumped and uneven, which was similar with the finding of Pokharel (2005) in Royal Suklaphanta Wildlife Reserve and Nagarkoti (2006) in Nagarjun Royal Forest. The clumped pattern of distribution is common in the nature, almost the rule, when individuals are considered. Random distribution, relatively rare in nature, occurs where the environment is very uniform whereas uniform distribution occurs where competition between individuals is severe or where there is positive antagonism which promotes even spacing (Odum 1971). In the forest of Hemja VDC the resources such as food, water resources and cover were not distributed uniformly leading to the uneven distribution of the species. Increasing human pressure to the forest resource might be another reason of uneven distribution of the species. Human disturbance and frequent pressure causes the fragmentation of the habitat along with continuous harassment to the animal's daily activities. It compels the animal to isolate into certain parts of the habitat.

Similarly, in Hemja VDC, middle range of the mountain is widely used by barking deer (Table-2 and 3). It might be due to the fact that the base of the mountain is excessively used by local people. Most of the area at the base is covered by cultivated grass and agriculture crops. So this was the area of high human disturbance. Similarly, somewhere, there was very steep mountain with less vegetation cover in the upper range of the mountain and mostly, there were human trails along the crest of the mountain. Moreover, middle range was least disturbed by human being and had high vegetation cover with natural springs for water source. That is why the middle range of the mountain was more suitable for the barking deer in Hemja area.]

Among three different blocks laid in the study area, block $\mathrm{A}$ and $\mathrm{C}$ had the higher fecal pellets density than that at block B. Block B was the southern face of the mountain which was comparatively drier than the other blocks which were faced to north of the mountain. Moreover, block A and $\mathrm{C}$ had denser vegetation cover than that in block $\mathrm{B}$. Among these three blocks, block A had highest density of fecal pellets (Table 1), it is because the area was least encroached by human activities, as it was far distance from the human settlement area.

In Hemja VDC, the mountains were steep. Almost all the deer were encountered in steep slope and even most of the evidences of this deer were also recorded in the steep mountains. It is therefore likely that the barking deer prefers sloping terrain and steeper hills and it is in agreement with Shrestha (2003).

Barking deer are mainly solitary and shy animals. They are unevenly distributed and clumped distribution pattern was exhibited in Hemja VDC. The results confirmed that they prefer middle range of the mountains which has dense canopy cover, proper water sources and less human disturbances. Hence, our efforts should be directed towards preserving wild forests with least human interference. 


\section{References}

Amato, G., M.G. Egan and A. Rabinowitz. 1991. A new species of muntjac, Muntiacus putaoensis (Artiodactyla: Cervidae) from northern Myanmar. Animal Conservation 2:1-7.

Chalise, M. K. 2000. Biodiversity of wild food plants in relation to the monkeys feeding ecology. In: Proceedings of $8^{\text {th }}$ international workshop of BIOREFOR, Japan, pp. 289-294.

Chalise, M. K. 2001. Nepalka Banyajantu, Bhag 2 (Nepal's Wildlife, Part 2), in Nepali. Natural History Society of Nepal, Kathmandu, 68 pp.

Dubost, G. 1970. L'organisation spatiale et sociale de Muntiacus reevesi Ogilby 1839 en semiliberte. Mammals 34:331-355.

Giao, P. M., D. Touc, V. V. Dung, E. D. Wikramanayake, G. Amato, P. Arctander and J. R. MacKinnon 1998. Description of Muntiacus truongsonensis, a new species of muntjac (Artiodactyla: Muntiacidae) from central Vietnam, and implications for conservation. Animal Conservation 1:61-68.

Heggdal, P. Ø. 1999. Spatial organization, habitat preferences and activity of barking deer (Muntiacus muntjac) during the dry season in Royal Bardia National Park, lowland, Nepal. M. Sc. thesis. Agricultural University of Norway.

Kurt, F. 1981. Muntjac deer. In: Grzimek's enclopedia of mammals (Vol.5). D. Grzimek, D. Badrian, D. Herre, R. Hess and M. Jones 1990. McGraw-Hill Publishing Company, New York. pp. 137-139.

Kurup, G.U. 1971. A foursome of barking deer (Muntiacus muntjac Zimerman). Journal of Bombay Natural History Society 68(2):445.

Nagarkoti, A. 2006. Distribution pattern, habitat preference and food habits of barking deer (Muntiacus muntjacZimmermann) in Nagarjun Royal Forest. M. Sc. dissertation. Central Department of Zoology, Tribhuvan University, Kirtipur, Kathmandu. 72 pp. Nowak, R. M. 1991. Order Artiodactyla. In: Walker's mammals of the world (5th ed) vol. 2. The Johns Hopkins Univ. Press, Baltimore, MD. pp. 1334-1400.

Odum, E. P. 1971. Fundamentals of Ecology. W.B Sanders Company, Philadelphia, USA.

Ohtaishi, N. and Y. T. Gao. 1990. A review of the distribution of all species of deer (Tragulidae, Moschidae and Cervidae) in China. Mammal Review, 20:125-144.

Pokharel, K. P. 2006. Ecological study of the barking deer Muntiacus muntjak (Zimmermann, 1780) in Hemja VDC, Kaski, Western Nepal. M.Sc. dissertation, Central Department of Zoology, Tribhuvan University. 60 pp.

Pokhrel, S. 2005. Distribution and abundance of wild ungulates in Royal Suklaphanta Wildlife Reserve. M. Sc. dissertation, Central Department of Zoology, Tribhuvan University, Kirtipur, Kathmandu.

Shi, L. M. and C. X. Ma. 1988. A new karyotype of muntjac (M. sp.) from Gongshan County in China. Zoological Research 9:343-347.

Shrestha, T.K. 2003. Wildlife of Nepal. B. Shrestha, Kathmandu, 720 pp.

Tamang, K. M. 1982. The status of the tiger (Panthera tigris) and its impact on the principal prey population in the Royal Chitwan National Park, Nepal. Ph.D. dissertation. Michigan State University, East Lansing, Michigan, USA.

Teng, L., Z. Liu, Y. L. Song and Z. Zeng 2004. Forage and bed sites characteristics of Indian muntjac (Muntiacus muntjac) in Hainan Island, China. Ecological Research 19:675-681.

Wang, W. and H. Lan 2000. Rapid and parallel chromosomal number reductions in muntjac deer inferred from mitochondrial DNA phylogeny. Mol. Biol. Evol. 17:1326-1333. 
Nepal Journal of Science and Technology 11 (2010) 223-228 